\title{
Farm Funds Optimisation For Community Entrepreneurship At Tobati Village Jayapura City
}

\author{
Yohanis Rante
}

\author{
Sarlota Arrang Ratang
}

\begin{abstract}
The village fund is expected village government and technical institutions can realize the vision of Jayapura city government that believes, independent, unified, modern, prosperous based local wisdom. The city of Jayapura has established the Community Entrepreneurship Agency (BKM) in each village/village/Kelurahan in order to manage the funds of the village/village/Kelurahan more effectively, efficient, precisely targeted to support the governance activities Good and transparent. The purpose of this research is to describe the management of ADD in village community empowerment as well as driving and inhibiting factors. The results showed that optimizing village funds allocation in the development of community entrepreneurship at Village Tobati Jayapura City is already running but not maximally, hence the need for strategy. STRATEGY (W-0) makes strategy that utilizes the opportunity to overcome weaknesses, namely consist of: Government policy that makes Village Tobati as a demonstration village for tourism, this is an opportunity to add Income or family's confidentiality. The help of Village fund, ADK, ADD the average routine each year. The commitment of the city government to improve and develop fisheries sector, especially the cultivation of fish cages very smooth and good means of transportation, and the help of the Prospect fund from the years 2016 and 2017 for the business of kiosk, sales Pinang, vegetable sales + Seasoning Kitchen, selling cold beverages + juice jacket, selling yellow rice, handicraft business, business selling pulse, oil kerosene + gasoline, net business. The opportunities mentioned above show that weaknesses in Village Tobati can be overcome well because of the very dominant opportunities in the village. Therefore the need for awareness from the local community to take advantage of the opportunities that exist for the welfare of the family in doing some very promising efforts.
\end{abstract}

Keywords: optimization, entrepreneurship and Tobati Village

\section{INTRODUCTION}

The village law has put the village as the spearhead of development and improvement of Community welfare. The village is given the adequate authority and resources in order to manage its potential to improve the economy and community welfare. Each year the central government has budgeted the village fund which is large enough to be given to the village. In addition, the village also had the opportunity to develop the community economy, through the training and marketing of handicraft society, business development Farms and fisheries, and the development of tourist areas through BUMDes (village-owned enterprises). The key to success for the welfare of the community in building a village is the strong touch of initiation, innovation, creation and cooperation between the village apparatus and the community in realizing the common ideals. Village development is unlikely to be done by the village apparatus itself, but it needs support, initiative, and active role of the community.

The important thing that can be applied in the management of village funds by involving the community is the need to conduct activities with the pattern of self-employed, using local 
workers, and utilizing local raw materials in the village. With the pattern of Swakelola, means that the planning and implementation of the activities are carried out independently by the village, so that the money used for the development will not flow out of the village. By using local workforce, it is hoped that the implementation of these activities can absorb labor and provide income for those who work.

The village fund is expected village government and technical institutions can realize the vision of Jayapura city government that believes, independent, unified, modern, prosperous based local wisdom. The city of Jayapura has established the Community Entrepreneurship Agency (BKM) in each village/village/Kelurahan in order to manage the funds of the village/village/Kelurahan more effectively, efficient, precisely targeted to support the governance activities Good and transparent. From the background of the existing "who have a village is the reign of Ondoafi in the village, then there are 10 legitimate village namely, Village Kayu Batu, Wood Pulo, Tobati, Enggros, Waena, Yoka, Nafri, Skouw Sae, Skouw Mabo, and Skouw Yambe the others we will remove," City leader of Jayapura. In this research, more focused on Village Tobati, South Jayapura village. At Village Tobati get funds in the year 2017 sourced from Desa Fund (DD), Village funds allocation (ADD), Tax share allocation (ABHP) with the amount of Rp. 2,789,948,805,-and also the source of funds derived from the prospect of Rp. 109.847.000. And for the economic field Rp. 76.6 million with the type of business that assisted is kiosk, sales Pinang, vegetable sales + seasoning Kitchen, selling cold beverages + juice coat, selling yellow rice, handicraft business, business selling pulse, oil kerosene + gasoline, net business

\section{Optimization}

\section{THEORETICAL REVIEW}

Optimizations according to the Bahasa Indonesia dictionary is the highest, most excellent, perfect, best, most profitable, optimizing means making perfect, making the highest, making the maximum, optimization means optimization. (Big Indonesian language). Optimization is the process of finding the best solution, not necessarily the highest profit that can be achieved if the goal of optimization is to maximize profits, or not always the least cost that can be suppressed if the purpose Optimization is minimising costs. (Hotniar Siringoringo, 2005:4).

\section{VILLAGE FUND}

According to Permendagri RI Number 114 Year 2014 Chapter 1 (Article 1, paragraph 1), village is customary or called by another name, hereinafter the village is the unity of the legal community that has the boundaries of the authority to govern and manage the affairs of government, The interests of the local community based on Community initiatives, rights of origin, and/or traditional rights recognized and respected in the unitary State government system of the Republic of Indonesia. According to Kamus Besar Bahasa Indonesia (2013) The village is a unity inhabited by a number of families with self-governing system (headed by a village chief) or village is a group of houses outside the city which is a Unity. Widjaja (2013) stated that "The village is a unity of the legal community that has a genuine arrangement based on the privilege of its origin." The foundation of thought in the governance of the village is diversity, participation, OTONOMIASLI, democratization and community empowerment.

According to Permendagri RI Number 113 Year 2014 village government is the implementation of government affairs and interests of local people in the system of unitary Republic of Indonesia. According to Awang (2010) "The village government is historically formed by the village community by selecting several members of the community who are believed to be able to organize, organize, serve, nurture and protect various aspects of their lives." Widjaja (2013) described Kepmendagri No. 64 year 1999 stating that the village 
government is "a government activity implemented by the Government of the BPD village." According to Soemantri (2010) The village government consists of village head and village device, while the village device consists of the village Secretary and other devices, namely the Village Secretariat, the technical implementation of the field and the regional elements, which amount Tailored to the needs and conditions of local social culture.

\section{Entrepreneurial}

Scarborough and Zimmerer in Novian (2012) define entrepreneurship (entrepreneur): Entrepreneurial is the one who creates a new business in the face of risk and uncertainty with the intention to gain profit and growth By recognizing opportunities and combining the resources needed to capitalize on those opportunities. Entrepreneurship is a mental attitude and a spirit that is always active or creative empowered, copyrighted, Berkarsa and understated in trying to increase income in its business activities (Amin, 2008). Thus, an entrepreneur must remain based on his ability to apply management functions so that the business they run can succeed well (Riyan in Handriyani (2011). Description of a selfemployed entrepreneur with risk-taking, self-employed functions including supervision, control, and providing direction for the company (Handriyani, 2011).

\section{Location and time of research}

\section{RESEARCH METHODS}

In accordance with the title of this research, the location of this research will be carried out village Tobati Jayapura City which is implementing the allocation program of village funds (ADD), the selection of research site based on consideration as a representation Region. The time of this research was conducted during May - October 2019

\section{Data retrieval Types and methods}

The data used in this research is the primary data of the identity of respondents and interviews to business actors in Village Tobati. The focus of this research is to know how to optimize Village fund allocation for Community entrepreneurship, as well as what are the factors that become the optimization of Special Village fund allocation in public business.

1. Literature study is data collection through written materials relevant to this research, such as literature and various documents and reports published by related agencies.

2. Field study is data collection where the author directly to the research object using the following research techniques:

1) Observation is one method of data collection intentionally, directed, systematic, and planned according to the objectives that will be achieved by observing \& record the entire incident and phenomenon occurring and referring to the terms and rules in the Research.

2) The interview is a method of collecting data in a systematic way to obtain information about the problems researched based on the research objectives.

\section{Population and Research samples}

The population in this study is all communities at the Village Tobati Jayapura City which has a business,. Samples are part of the number and characteristics that the population belongs to. (Sugiyono, 2013:118). The technique that is done in sampling is using sampling techniques purposive the sampling technique with certain considerations (Sugiyono, 2013:124). Selected samples by looking at the same characteristics that are the community that has a business in the village Tobati Jayapura City as many as 22 respondents. 


\section{Technical analysis of data}

Measuring scale is an instrument that is a reference deal in the measuring instrument, so that the measuring instrument when used in research will produce quantitative data. In the Alpian states there is a likert scale that can be used in research. Where this Likert scale is used to describe as an indicator that is then used as a benchmark in the preparation of the question items. The answers on Likert scales can be the following words:

Strongly Agree (SS) $=5$

Agree (4) = 4

No idea $(\mathrm{TT})=3$

Disagree $(\mathrm{TS})=2$

Strongly Disagree (STS) $=1$

SWOT analysis is systematically identifying various factors to formulate strategies. This analysis is based on the logic that can maximize strengths (Strengths) and opportunities (opportunities), but simultaneously minimizes weaknesses (Weaknesses) and threats (Threats). Strategic Planner A company should analyze the strategic factors of the company (strengths, weaknesses, opportunities, and threats) at the existing Kondisi. This is called a situation or popular analysis called Analyisisswot. In analyzing data used qualitative descriptive technique to answer the formulation of the problem of what is the strength and weakness of the object of research and what are the opportunities and threats from outside the He faced.

\section{RESULTS AND DISCUSSION}

Of the 22 respondents who became one of the important data sources in this study, after being given questions about community perception regarding the optimization of village funds for entrepreneurship in the form of a questionnaire that was summarized in the answer Statement

A. of 22 respondents, $63.6 \%$ or 14 respondents said they do not know about the village fund to facilitate SMES. Meanwhile, stating that there is a village fund for MSMES, there are $34.4 \%$ or 8 respondents. This is because there are approximately $37 \%$ of respondents who have received business assistance in the form of physical enterprises such as keramba making rocks, fish seedlings, etc. While other businesses are $64 \%$ who have not received the village funds aid for their efforts.

B. Information obtained by the respondent about the Village fund that conducts some community training for the business that has been done. From the answers of respondents who gained 20 respondents (17.6\%) Answer very concur (SS) the existence of village funds in providing business shutdown, because so far there are several shutdown activities that have been done in attracting the community to start the business or business that has been running to continue to be developed. While only $2 \%$ who stated not know because there has been no time to participate in the training activities that are carried out with some reasons.

C. Respondents as much as $100 \%$ or 22 Respoden replied strongly agree that the village funds can provide an increase in the family economy when it can be given in accordance with the existing business blindness with transparency and sustainability, remain on strict supervision For the right help of the target..

D. The knowledge of entrepreneurship is also one of the questions of the questionnaire given. The respondent's answer was 21 respondents or $88.8 \%$ answered strongly agree to take the village fund once given the knowledge of entrepreneurship through the undoing. As with the table above the business shutdown, it is where the knowledge of the business is explained.

E. The community got a chance to become a businessman through Village funds. The respondents ' answers are as many as 10 respondents (45.4\%) Of Total respondents 
replied that they said strongly disagree that the village funds give them to be entrepreneurs. Because they make business not because of the village funds but because of personal funds in the start of business. While 8 Respoden or $18.2 \%$ said agree because it is to raise the aid of the village funds for the grant so that it had not been a business, thanks to the village funds can be a businessman.

F. Every month to get supervision or control over the running business, the respondent's answer is as many as 10 respondents (45.4\%) Of Total respondents replied that they say strongly disagree that the village funds give employees related to their efforts, because during this time the village is not doing supervision, but who are used to supervise or From the Fisheries Department.

SWOT analysis to analyze what are the driving factors and the impetus management of village funds allocation in the development of community entrepreneurship at Village Tobati Jayapura City

\section{Power}

1. Village community interest for fish farming in cages is very high

2. The support of village funds, village allocation fund, tax share allocation

3. Support local government in the empowerment and development of community business in the village

4. Experience in cages business has been long enough

5. The establishment and development of BUMKam

6. Natural resources that are very supportive in addition to the business also the potential of tourism because it is above the water and the sea view is very beautiful and charming also pumpkin housing is again in the eyeing by tourists.

7. Being around the Red bridge is very beautiful scenery

\section{Weakness}

1. Assistance in the form of fish seedlings and manufacturing of cages that is not managed by the community

2. Community village more that doing activities in the city than in the village connected to the distance is quite close to the city of Jayapura

3. Lack of openness in the management of village/Kampug funds for business

4. In infiltrate the documents of the village take a long time so that when PemKot require data to experience literature

5. During the village funds, Dinas associated with less response to the activities of the village

6. Water quality for the cultivation of cages fish is not good because it is exposed to construction pollution bridge Ring Road

7. The limited knowledge of the Continueu entrepreneurship and limited business capital

8. Lack of mentoring in conducting business

9. Unfinished Village Tobati Office

\section{Opportunities}

1. The city government policy that makes Village Tobati as a demonstration village for tourism, this is an opportunity to increase income or family

2. The presence of village funds, ADK, ADD the average routine per Taun

3. Commitment of city government to improve and develop fisheries sector, especially the cultivation of fish cage

4. Very smooth and good means of transportation 
5. Help fund prospects from the year 2016 and 2017 for business kiosk, sales Pinang, vegetable sale + seasoning Kitchen, selling cold beverages + juice jacket, selling yellow rice, handicraft business, business sales pulse, petroleum business + gasoline, net business

\section{Threat}

1. Waste with the existence of Ring Road Bridge project reduce water quality in aquaculture Perkanan

2. Lack of attention and transparaansi the village apparatus in Mengola Village Fund

3. The village community does not trust the village apparatus in explaining the PTO and other rules regarding the village fund

4. Village head that does not settle in Village

The results of the calculation show that the meeting point is in the Quadrant I (positive, positive) This position proves an entrepreneurial activity that runs on Village Tobati is still in a strong and likely condition. The recommendation of tactics provided is progressive, meaning in the economic field for business problems in a prime and steady condition. So it is really possible to continue to run the expansion, increase growth and achieve maximum progress, although there are still many shortcomings here but it is not a barrier to moving forward.

STRATEGY (W-O) makes strategy that utilizes the opportunity to overcome weaknesses, namely consist of: Government policy that makes Village Tobati as a demonstration village for tourism, this is an opportunity to add Income or family's confidentiality. The help of Village fund, ADK, ADD the average routine each year. The commitment of the city government to improve and develop fisheries sector, especially the cultivation of fish cages very smooth and good means of transportation, and the help of the Prospect fund from the years 2016 and 2017 for the business of kiosk, sales Pinang, vegetable sales + Seasoning Kitchen, selling cold beverages + juice jacket, selling yellow rice, handicraft business, business selling pulse, oil kerosene + gasoline, net business. The opportunities mentioned above show that weaknesses in Village Tobati can be overcome well because of the very dominant opportunities in the village. Therefore the need for awareness from the local community to take advantage of the opportunities that exist for the welfare of the family in doing some very promising efforts. It is hoped that the public should utilize government assistance to be well-managed, the community is expected to remain in the village to be able to build together, but it is expected that the Kampong apparatus to open (transparency) problems The funds are given to the village.

\section{Conclusion}

\section{CONCLUSION AND ADVICE}

A. Results show that optimizing village funds allocation in the development of community entrepreneurship at Village Tobati Jayapura City is already running but not maximally, this is according to the results of the research with respondents 22 business actors and According to them that the village funds to facilitate SMES, the results showed that there are at least $63.6 \%$ or 14 respondents said that there is no idea about the village fund in expediting SMES. Next about the village fund that conducts some community training for the business that has been done.. From the answers of respondents who gained 20 respondents (17.6\%) To answer very concur (SS) of community training conducted. For the Village fund provides economic increase, all respondents $100 \%$ answered strongly agree (SS). Furthermore, from 21 respondents or $88.8 \%$ answered strongly agree that the village funds have given knowledge about entrepreneurship through the training of business conducted. And the last is the community got the opportunity to become entrepreneurs through the village funds. The respondents ' answers are as many as 10 
respondents (45.4\%) Of Total respondents replied that they said strongly disagree that the village funds give them to be entrepreneurs. Because they make business not because of the village funds but because of personal funds in the start of business. While 8 Respoden or $18.2 \%$ say agree because it gets the help of the Village fund for its business so that it has not had any effort, thanks to the village funds can be a businessman. And respondents ' answers to surveillance on their efforts show that 10 respondents (45.4\%) Shows strongly disagree because of the lack of oversight of the related parties about the business that is running.

B. The strategy to be done for entrepreneurship at Village Tobati is STRATEGY (W-O) making strategy that utilize the opportunity to overcome the weakness, namely consist of: Government policy that makes Village Tobati as Village For tourism, this is an opportunity to increase income or family's confidentiality. The help of Village fund, ADK, ADD the average routine each year. The commitment of the city government to improve and develop fisheries sector, especially the cultivation of fish cages very smooth and good means of transportation, and the help of the Prospect fund from the years 2016 and 2017 for the business of kiosk, sales Pinang, vegetable sales + Seasoning Kitchen, selling cold beverages + juice jacket, selling yellow rice, handicraft business, business selling pulse, oil kerosene + gasoline, net business. The opportunities mentioned above show that weaknesses in Village Tobati can be overcome well because of the very dominant opportunities in the village. Therefore the need for awareness from the local community to take advantage of the opportunities that exist for the welfare of the family in doing some very promising efforts. It is hoped that the public should utilize government assistance to be well-managed, the community is expected to remain in the village to be able to build together, but it is expected that the Kampong apparatus to open (transparency) problems Funds given to the village

\section{Advice}

A. Need openness (transparency) of the village apparatus regarding the use of funds for the village.

B. The technical service is expected to be more serious in implementing the activities Program in the village

\section{BIBLIOGRAPHY}

Tim Prima Pena, dictionary great Bahasa Indonesia, (Gita Media Press, 2015). H. 562

Hotniar Siringoringo, Linear Programming: Engineering series of Operations Research, (Yogyakarta: Graha Ilmu,2005). H. 4

Widjaja HAW, Government village/Marga, Raja Grafindo Persada, Jakarta, 2013

Awang, Azam. 2010. Implementation of village governance empowerment. Yogyakarta: Student Library.

Bambang Trisantoro Soemantri, 2011, "Guidelines for implementation of village government", Fokusmedia, Bandung.

Novian, Deni. 2012. The influence of entrepreneurship education on student motivation to become an entrepreneurial. (Thesis). University of Lampung. Bandar Lampung.

Widjaja, Solo, Amin. 2007. FAQs for organizational culture. Jakarta, publisher of Harvarindo, 2004.

Eka Handriani, (2011), influence external Internal factors, Entrepreneurial skills, strategy and performance to the competitiveness of SMEs in Semarang Regency, Journal of Social Economic Dynamics, Vol 7, No 1, May 2011; 4769.

Permendagri RI Nomor 114 Tahun 2014

Permendagri RI Nomor 113 Tahun 2014

Kepmendagri No. 64 Tahun 1999 